\title{
Determination of antioxidant and antimicrobial activity of sweetgum (Liquidambar orientalis) leaf, a medicinal plant
}

\author{
Hatice Ulusoy ${ }^{1}$ (D), Şule Ceylan² (D) and Hüseyin Peker ${ }^{2 *}$ (D) \\ ${ }^{1}$ Department of Forestry, University of Muğla Sıtkı Koçman, Muğla, Turkey \\ ${ }^{2}$ Department of Forest Industry Engineering, University of Artvin Çoruh, Artvin, Turkey \\ *peker100@hotmail.com
}

\begin{abstract}
In the study, sweetgum tree (Liquidambar orientalis), which is an endemic species that grows in Mugla, Köyceğiz and is applied for medicinal purposes among the public, its leaves was examined. The antioxidant ability of the extract obtained from dried plant leaves has been evaluated using a variety of methods which are Total Phenolic Substance, Total Flavonoid, FRAP, CUPRAC, DPPH, and ABTS ${ }^{+}$. Simultaneously, the antimicrobial activity of the plant extract was examined using disk diffusion and microdilution methods to determine the minimum inhibitor concentration (MIC). While the total phenolic content of Liquidambar orientalis extract was $96.34 \mathrm{mg} \mathrm{GAE} / \mathrm{g}$, the total amount of flavonoid was $2.15 \mathrm{mg} \mathrm{QE} / \mathrm{g}$. When the results of the antioxidant analysis were examined, it was observed that it had a good level of antioxidant activity with the results of $49.25 \pm 0.54 \mathrm{mmol}$ TEAC/g according to the CUPRAC method, $39.83 \pm 0.25$ $\mu \mathrm{mol} \mathrm{Fe} / \mathrm{g}$ according to the FRAP method, $80.34 \mu \mathrm{g} / \mathrm{mL}$ according to the DPPH method and $51.20 \mu \mathrm{g} / \mathrm{mL}$ according to the ABTS+ method. As a result of the antimicrobial analysis, it was indicated that L. orientalis extract was more effective on Staphylococcus aureus (S. aureus), which is a gram-positive bacterium and causes a wide variety of clinical diseases. Even, L. orientalis extract with an MIC value of $10 \mathrm{mg} / \mathrm{mL}$ has been found to have a higher antibacterial effect than Amoxicillin+Clavulanic acid, which is used as a standard drug in that field. This research is significant because it is the first to report the determination of all biological activities for L. orientalis, including total polyphenols, flavonoid contents, antioxidant content, and antimicrobial activity.
\end{abstract}

Keywords: sweetgum tree, diary tree, medicinal plant, antioxidant, antimicrobial.

How to cite: Ulusoy, H., Ceylan, Ş., \& Peker, H. (2021). Determination of antioxidant and antimicrobial activity of sweetgum (Liquidambar orientalis) leaf, a medicinal plant. Polímeros: Ciência e Tecnologia, 31(2), e2021015. https:// doi.org/10.1590/0104-1428.04221

\section{Introduction}

From past to present, people have benefited from plants for nutrition, shelter, heating, healing wounds and curing diseases. It has been determined that there are 250 plants that people used in treatments in the 5000s B.C. Hittites, Egyptians, Sumerians, Assyrians and Mesopotamians have used herbs for years. The introduction of synthetic drugs into production over time has led to a decrease in the use of medicinal and aromatic plants. However, after the 1900s, when people discovered the side effects of synthetic drugs and became aware of the harmful effects of synthetic substances in food and beverages on human health, the demand for natural products increased ${ }^{[1]}$.

Many medicinal plants have been discovered by humankind by trial and error. In Turkey, medicinal aromatic plants are commonly used in daily life to treat a variety of diseases. Turkey is an attractive source of medicinal plants because of its diverse flora and attention to a variety ${ }^{[2]}$. It is known that plant extracts and components exhibit important biological activities, especially antimicrobial ${ }^{[3]}$, antifungal ${ }^{[4]}$, antibacterial ${ }^{[5]}$, and antioxidant activities ${ }^{[6]}$. Most medicines are now manufactured pharmacologically, with herbal origins accounting for $25 \%$ of them. Free radicals are generated throughout the body by the toxic air we breathe during the day, poisonous compounds in spoiled foods, additives, unconscious eating, and inactivity. Oxygen atoms broken off by these harmful effects from outside circulate freely in the body, breaking down hydrogen atoms and causing tissue damage. Free radicals especially attack the cell and immune system. Molecules that minimize and block the effect of free radicals in the body and prevent chain reactions that may cause many diseases and premature aging are called "antioxidant" substances ${ }^{[7]}$. Prevention of free radical-mediated reactions that lead to difficult-to-treat problems such as aging, cancer, and diabetes is only possible with the help of antioxidant compounds ${ }^{[8]}$. As is known, antioxidants are mostly found in green and red-leaved plants. At the same time, vitamins $\mathrm{A}, \mathrm{C}$, and $\mathrm{E}$ show natural antioxidant properties $^{[7]}$.

Due to the increase of microorganisms with multiple antibiotic resistance in recent years, the treatment of the infection caused by these microbes has become increasingly 
intractable. Drug resistance increases and spreads in bacteria that develop resistance to all known antibiotics. As a result, using medicinal plants as an alternative to medications is recommended, and some popular herbs are used as antimicrobials ${ }^{[9]}$. Many phytochemical compounds are found in vegetable-derived products, and they have been shown to have high antioxidant and antimicrobial properties in the literature ${ }^{[10]}$. Plant extracts and essential oils have been studied extensively for their antioxidant and antimicrobial properties $^{[11]}$.

Many phytochemical compounds are found in vegetablesourced products, and they have been shown to have high antioxidant properties as well as good antimicrobial activity in the literature ${ }^{[10]}$. There are many studies on the antioxidant and antimicrobial properties of plant extracts and essential oils $^{[11]}$. There have been studies that show the sweetgum tree, which is an endemic species to the Muğla area, has medicinal properties. Liquidambar orientalis, known locally as the sweetgum tree, and its products (leaves, bark, sweetgum oil, etc.) have the natural protective potential ${ }^{[12-14]}$. Liquidambar orientalis ${ }^{[15]}$, one of the four sweetgum tree species present in Turkey today, has been around for about 60 million years. People living in the province of Muğla and its surroundings apply sweet gum trees for shortness of breath, bronchitis, and so on. It is also applied as incense because it helps the healing process of respiratory system diseases. In addition, the essential oil extracted from sweetgum trees is used in the formulation of many natural perfumes, as well as in the soap industry and in the fragrance of gum and tobacco. It is also claimed that it is used in the form of pomade and patch against skin diseases such as scabies, fungus, stomach, and duodenal ulcers, as well as being a healthy antiseptic and parasitic $^{[12-14]}$.

In light of this knowledge, the antioxidant and antimicrobial properties of the leaf of the sweetgum tree (L. orientalis), which plays an important role as a medicinal aromatic plant, were investigated in this research.

\section{Materials and Methods}

\subsection{Material (chemicals/plant)}

2,4,6-tripyridyl-s-triazine(TPTZ), Folin-Ciocalteu's phenol reagent, Methanol, 2,2-diphenyl-1-picrylhydrazyl (DPPH) and Trolox (6-hydroxy-2,5,7,8-tetramethylchroman2-carboxylic acid), 2,2'-azinobis (3-ethyl-beothiazoline 6 sulfonate) (ABTS) were acquired from Sigma Chemical Co. (St. Louis, MO, USA). Neocuproine (2,9-dimethyl1,10-phenanthroline), acetic acid, ammonium acetate, aluminium nitrate nonahydrate, potasyum persülfat $\left(\mathrm{K}_{2} \mathrm{~S}_{2} \mathrm{O}_{8}\right)$, and sodium carbonate, were bought from Merck Chemical Co. (Darmstadt, Germany). The chemicals were analytical degrees. The subject of the study is L. orientalis (sweetgum) leaves and the herbal material was obtained from MuğlaKöyceğiz. L. Orientalis plant was authenticated by Prof. Dr. Temel Göktürk, a forest engineer. The dried sweetgum leaves are powdered. Powdered sweetgum leaves were extracted by brewing method with distilled hot water $\left(80^{\circ} \mathrm{C}\right)$. After the mixture had cooled, filtration was carried out with Whatman grade 1 filter paper. The obtained filtrate was then dried under vacuum with a freeze-dryer (lyophilizer) system, model Christ Freeze-Dryer Alpha 1-4 LD, and the crude extract was obtained. Solutions of different concentrations of the extract obtained were prepared and biological activity analyzes such as antioxidant and antimicrobial were tested.

\subsection{Total phenolic assay}

The total phenolic amount of samples was detected by using the Folin-Ciocalteu test ${ }^{[16]}$. Gallic acid (1;0.5; 0.25; $0.125 ; 0.0625$ and $0.03125 \mathrm{mg} / \mathrm{mL}$ ) was used as a standard in this work. Shortly, $400 \mu \mathrm{L}$ of $0.5 \mathrm{~N}$ Folin-Ciocalteu tests, $20 \mu \mathrm{L}$ methanolic plants $(1 \mathrm{mg} / \mathrm{mL}), 680 \mu \mathrm{L}$ of distilled water, and $20 \mu \mathrm{L}$ of different concentrations of gallic acid were mixed and the mixture was vortexed. $400 \mu \mathrm{L}$ of $\mathrm{Na}_{2} \mathrm{CO}_{3}(10 \%)$ solution was added after 3-minute incubation and again vortexed. Then the mixture was incubated for 2 hours. Following the incubation time at room temperature, absorbances of the mixtures were determined at $760 \mathrm{~nm}$. The concentrations of total phenolic compounds were measured as mg of gallic acid equivalents per $g$ of the dry weight of the sample.

\subsection{Total flavonoid assay}

The total flavonoid amount was determined by using the aluminum chloride test ${ }^{[17]}$. Quercetin was used as a standard. $4.3 \mathrm{~mL}$ methanol, $0.1 \mathrm{~mL} 1 \mathrm{M} \mathrm{NH}_{4} \mathrm{CH}_{3} \mathrm{COO}, 0.5 \mathrm{~mL}$ of Quercetin $(1 ; 0.5 ; 0.25 ; 0.125 ; 0.0625$ and $0.03125 \mathrm{mg} / \mathrm{mL})$, and $0.1 \mathrm{~mL} 10 \% \mathrm{Al}\left(\mathrm{NO}_{3}\right)_{3}$ were put in the tubes and then they were mixed. Mixtures were incubated for 40 minutes. Following incubation, absorbance was determined at $415 \mathrm{~nm}$. The total flavonoid contents of plants were defined as $\mathrm{mg}$ quercetin equivalents per $g$ of dry weight sample.

\subsection{The determination of antioxidant activity}

The antioxidant activities of the samples were determined using by FRAP and CUPRAC methods. The FRAP method was used for the determination of total antioxidant capacity, based on the reduction of yellow $\mathrm{Fe}_{3}{ }^{+}$-TPTZ complex to the blue $\mathrm{Fe}_{2}{ }^{+}$-TPTZ complex by electron-donating substance under acidic conditions ${ }^{[18]}$. The $3 \mathrm{~mL}$ of FRAP reagent (containing TPTZ, $\mathrm{FeCl}_{3}$, and acetate buffer) and $100 \mu \mathrm{L}$ of the test sample or the blank (solvents used for extraction) were added to the test tube and mixed. Maximum absorbance values at $593 \mathrm{~nm}$ were recorded for $4 \mathrm{~min}$ at $25^{\circ} \mathrm{C}$. The final absorbance was compared with the standard curve (100-1000 $\mu \mathrm{mol} / \mathrm{L})$.

The data were expressed as $\mu \mathrm{mol} \mathrm{FeSO}{ }_{4} .7 \mathrm{H}_{2} \mathrm{O}$ equivalents per gram of dry matter. The CUPRAC method is comprised of mixing the antioxidant solution (directly or after acid hydrolysis) with a copper (II) chloride solution, a neocuproine alcoholic solution, and an ammonium acetate aqueous buffer at $\mathrm{pH} 7$, and subsequently measuring the developed absorbance at $450 \mathrm{~nm}$ after 60 minutes $^{[19]} 1 \mathrm{~mL} 10 \mathrm{mM}$ $\mathrm{CuCl}_{2}, 1 \mathrm{~mL} 7.5 \mathrm{mM}$ Neocuproine and $1 \mathrm{~mL} 1 \mathrm{M} \mathrm{NH}_{4} \mathrm{Ac}$ were added to test tubes, then $0.2 \mathrm{~mL}$ sample and $0.9 \mathrm{~mL}$ $\mathrm{H}_{2} \mathrm{O}$ were added and mixed. The final volume was $4.1 \mathrm{~mL}$. Then, the final absorbance was measured at $450 \mathrm{~nm}$ after incubated $1 \mathrm{~h}$. The test results were evaluated by Trolox ${ }^{\circledR}$ equivalent antioxidant capacity (TEAC).

The scavenging activity of DPPH $\bullet$ radical was determined using the method of Molyneux ${ }^{[20]}$. Different concentrations 
of $0.75 \mathrm{~mL}$ of sample extracts were mixed with $0.75 \mathrm{~mL}$ of a $0.1 \mathrm{mM}$ of DPPH $\bullet$ solution (dissolved in methanol). Then, extracts were incubated at room temperature in the dark for $50 \mathrm{~min}$. Absorbance was measured by a spectrophotometer at $517 \mathrm{~nm}$. Trolox is used as standards and the values are expressed as $\mathrm{IC}_{50}$ (mg sample per $\mathrm{mL}$ ). The method developed by Re et al. ${ }^{[1]}$ was applied to assess $\mathrm{ABTS}^{+}$removal activity. This method is based on the principle that the colored ABTS $\bullet^{+}$cation radical changes color after treatment with the extract. $5 \mathrm{~mL} \mathrm{ABTS} \bullet^{+}$cation radical was prepared by mixing ABTS $(7 \mathrm{mM})$ solution with $2.45 \mathrm{mM}$ potassium persulfate $\left(\mathrm{K}_{2} \mathrm{~S}_{2} 0_{8}\right)$ solution and incubated for 16 hours in the dark and at room temperature. By diluting $1 \mathrm{~mL}$ of this radical solution with ethanol, the absorbance was adjusted. At concentrations ranging from $500 \mathrm{~g}$ to $4000 \mathrm{~g}, 4 \mathrm{~mL}$ of ABTS solution prepared in ethanol was applied to samples containing $1 \mathrm{~mL}$ of sample. As a control, $1 \mathrm{~mL}$ of ethanol was used. At $734 \mathrm{~nm}$, radical scavenging activity was measured after a 10-minute incubation period at room temperature.

\subsection{The biological materials}

All three microorganisms were used in this work. As bacteria; Escherichia coli (E. coli) ATCC 25922, Staphylococcus aureus (S. aureus) ATCC 6538P, as yeast: Candida albicans (C. albicans) ATCC 14053. All test microorganisms were got from the American Type Culture Collection (ATCC), the Faculty of Science of Muğla University, and the commercial culture collections. All microorganisms were stored at $-85^{\circ} \mathrm{C}$ (Ultrafreezer, New Brunswick) in 15\% glycerol and protected on nutrient agar (Merck, 1.05450) and malt extract agar (Merck, 1.05398) slants at $4{ }^{\circ} \mathrm{C}$, respectively. They were subcultured in Petri dishes before use for purity check. The microorganisms chosen for the antibacterial property studies are between significant herb and man pathogens and biofilm giving microorganisms.

\subsection{In vitro antimicrobial activity}

\subsubsection{Disk diffusion method}

The disk diffusion approach was used to investigate the effects of beef extract on Escherichia coli ATCC 25922, Staphylococcus aureus ATCC 6538P, and Candida albicans ATCC $14053^{[22]} .1000 \mathrm{~mL}$ of liquid cultures that had reached $0.5 \mathrm{McFarland}$ normal turbidity were transferred to sterile petri dishes, along with approximately $20 \mathrm{~mL}$ of Mueller Hinton Agar (Merck) for bacteria and Sabouraud Dextrose Agar (Merck) for C. albicans, and planting was done using disc diffusion method. Then, disks soaked with $20 \mu \mathrm{L}$ of extract (at $400 \mathrm{mg} / \mathrm{mL}$ concentration) were appropriately placed on the agar. Sowed petri dishes were incubated for $S$. aureus and E. coli for 24 hours at $37 \pm 0.1{ }^{\circ} \mathrm{C}$ and for C. albicans at $37 \pm 0.1{ }^{\circ} \mathrm{C}$ for 48 hours. The diameter of the inhibition zones formed around the discs was measured in $\mathrm{mm}$ at the end of the incubation. Bacteria, Amoxicillin+Clavulanic acid disc (Oxoid) for E. coli and S. aureus, and nystatin (Oxoid) for yeast strain C. albicans were used as positive controls, as was sterile distilled water in which plant extract was dissolved as a negative control. All three experiments were conducted in parallel.

\subsubsection{Broth microdilution test for bacteria}

The minimum inhibition concentration (MIC) values of the extract on $S$. aureus, which was used in the study and whose inhibition effect was detected by the disk diffusion method, were determined by the broth microdilution $\operatorname{method}^{[23]}$. Serial dilutions of the extract $(80,40,20,10$, and $5 \mathrm{mg} / \mathrm{mL}$ ) were performed using (Mueller Hinton Broth (Merck) with a final volume of $2 \mathrm{~mL}$. Bacterial suspensions were prepared at a concentration of $10^{6} \mathrm{CFU} / \mathrm{mL}$ (using Mac Farland No: 0.5) with turbido for each test bacteria and $20 \mu \mathrm{L}$ of suspension was added to each test tube. Tubes were incubated at $37 \pm 0.1{ }^{\circ} \mathrm{C}$ for 48 hours and the lowest concentration without bacterial growth was determined as MIC. Measurements were carried out in triplicate and the results of the antimicrobial test were compared with standard Amoxicillin+ Clavulanic acid as antibacterial agents.

\section{Results and Discussions}

\subsection{Extract (solution) feature}

There are numerous diverse antioxidants in plants, and it is very difficult to measure each antioxidant component individually. The chemical complexity of the extracts, often a mixture of dozens of compounds with different functional groups, polarity, and chemical behavior, can lead to varying results depending on the test used. Therefore, it is more informative to utilize diverse tests to assess the antioxidant potential of each test ${ }^{[24,25]}$. In this research, four fundamental strategies, CUPRAC (copper decreasing control), FRAP (ferric decreasing control), $\mathrm{DPPH} \bullet$ and $\mathrm{ABTS} \bullet{ }^{+}$radical scavenging activity strategies were utilized.

At the same time, total phenolic and flavonoid contents were determined for the extract. In these tests, the UV spectrophotometric method was applied. Spectrophotometric strategies are frequently utilized for the standardization of natural raw materials. Total phenolic and total flavonoid contents, FRAP and CUPRAC values are presented in Table 1 and the results shown in the tables refer to the average $\pm \mathrm{SD}$ of three parallel measurements. $\mathrm{IC}_{50}$ values determined from DPPH and $\mathrm{ABTS}^{+}$analyzes are given in Figure 1 and Figure 2. $\mathrm{IC}_{50}$ values were calculated from linear regression analysis (Microsoft Excel, Microsoft Corporation $\AA$, USA).

The total polyphenol content of $L$. orientalis leaf extract, which is endemic in the Muğla region, was $96.34 \pm 1.75 \mathrm{mg}$ $\mathrm{GAE} / \mathrm{g}$, and the total flavonoid content was calculated as $2.15 \pm 0.36 \mathrm{mg} \mathrm{QE} / \mathrm{g}$. According to the antioxidant activity results, it was found to have $49.25 \pm 0.54 \mathrm{mmol} \mathrm{TEAC} / \mathrm{g}$ according to CUPRAC analysis and $39.83 \pm 0.25 \mu \mathrm{mol} \mathrm{Fe} / \mathrm{g}$ according to FRAP analysis. According to the antioxidant activity results, it was found to have $49.25 \pm 0.54 \mathrm{mmol}$

Table 1. Results of phenolic contents, flavonoid contents, FRAP and CUPRAC for L. orientalis medicinal plant.

\begin{tabular}{ccccc}
\hline Sample & Total phenolics (mg GAE/g) & Total flavonoid (mg QE/g) & CUPRAC (mmol TEAC/g) & FRAP $(\boldsymbol{\mu m o l ~ F e / g ) ~}$ \\
\hline L. orientalis & $96.34 \pm 1.75$ & $2.15 \pm 0.36$ & $49.25 \pm 0.54$ \\
\hline
\end{tabular}


TEAC/g according to CUPRAC analysis and $39.83 \pm 0.25 \mu \mathrm{mol}$ $\mathrm{Fe} / \mathrm{g}$ according to FRAP analysis (Table 1). When DPPH and $\mathrm{ABTS}^{+}$radical scavenging activity results are examined, it is given that it has $\mathrm{IC}_{50}$ concentrations of $80.34 \mu \mathrm{g} / \mathrm{mL}$ for DPPH and $51.20 \mu \mathrm{g} / \mathrm{mL}$ for ABTS+ (Figure 1 and Figure 2). According to these results, it is observed that ABTS+radical scavenging activity of $L$. orientalis leaf is higher than DPPH radical scavenging activity.

In the antimicrobial activity studies of the aqueous extract tested against microorganisms in the current study, the inhibition diameters obtained according to the disk diffusion method are given Figure 3 and Table 2, and the minimum inhibition concentrations (MIC) results are presented in Table 3.

\subsubsection{Staphylococcus aureus (S. aureus) ATCC 6538P}

When the antimicrobial activity of $L$. orientalis leaf extracts was evaluated in vitro against three test microorganisms known to cause some diseases in foods. According to the antimicrobial activity results obtained, It has been found,

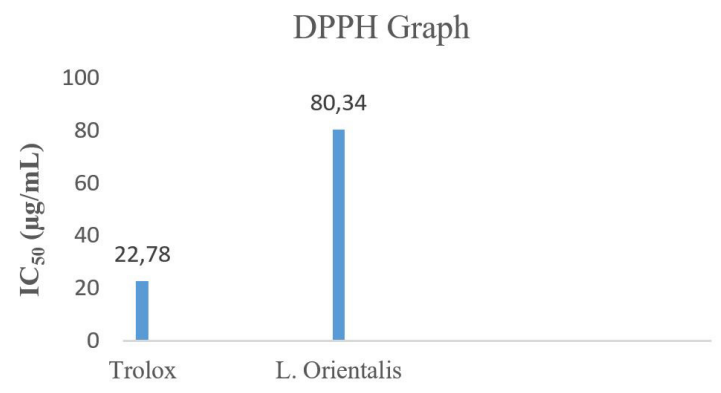

Figure 1. The result of DPPH for L. Orientalis extract.

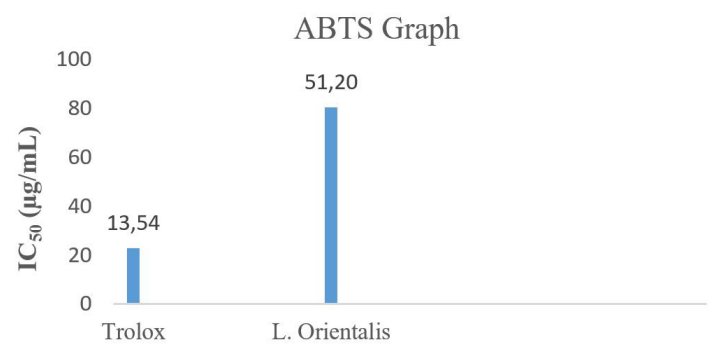

Figure 2. The result of $\mathrm{ABTS}^{+}$for L. Orientalis extract. while L. orientalis plant extract does not show any activity against $E$. coli, a gram-negative bacterium, and C.albicans, a yeast strain, $L$. orientalis plant extract shows very good activity against $S$. aureus, which is a gram-positive bacterium, causing various clinical diseases. While the MIC value obtained for $L$. orientalis has a concentration of $10 \mathrm{mg} / \mathrm{mL}$, the MIC value of Amoxicillin+Clavulanic Acid, which is used as a standard drug in that area, is $40 \mathrm{mg} / \mathrm{mL}$. Therefore, L. orientalis extract antibacterial activity is much higher than the standard drug used in that field.

Medicinal plants are traditionally applied worldwide for the treatment of various human diseases ${ }^{[26]}$. Many of these have proven to be abundant sources of biologically active compound ingredients used as a tool to develop new pharmaceutical compounds ${ }^{[27]}$. Although the antibacterial and antioxidant activities of many plant species have been extensively investigated, the antimicrobial and antioxidant mechanism of the $L$. orientalis plant included in this research has not been reported in detail.

The research conducted in İzmir, Turkey ${ }^{[28]}$, on L. orientalis leaves obtained from Mugla like in our study, the total polyphenol amount for the leaves of the plant was found as $0.37 \mathrm{mg} \mathrm{GAE} / \mathrm{g}$ and this value was found to be much higher as $96.34 \pm 1.75 \mathrm{mg} \mathrm{GAE} / \mathrm{g}$ in our study. Although the plant was obtained from the same region, the extraction solvent was a 70\% aqueous ethanol solution in the study conducted in Izmir, while only water was used as the extraction solvent in our research. The number of phenolic compounds found in plants; solvents are affected by many factors such as temperature, extraction time, particle size, sample type, and extraction methods ${ }^{[29]}$. According to the antimicrobial activity results, while the MIC value against $S$. aureus was $0.4 \mathrm{mg} / \mathrm{mL}$ in the literature ${ }^{[28]}$, this value is $10 \mathrm{mg} / \mathrm{mL}$ in our study. L. orientalis leaf extract has shown the highest antibacterial activity against $S$. aureus, which causes various diseases, both in our study and in the literature. Additionally, according to the study conducted in İzmir, ABTS ${ }^{+}$radical removal activity was 8.009 TEAC ( $\mathrm{mmol} / \mathrm{g}$ sample), whereas in our study it was investigated to have antioxidant activity with a value of $51.20 \mu \mathrm{g} / \mathrm{mL}$.

In a research conducted by Saraç and Şen ${ }^{[30]}$, DPPH radical scavenging activity was investigated to be $3.11 \pm 0.024 \mathrm{mg} / \mathrm{mL}$ for the ethanol extract of $L$. orientalis leaf obtained from Köyceğiz, Muğla. In our study, for the extract of L. orientalis leaf in water, DPPH radical scavenging activity value was measured as $0.080 \pm 0.42 \mathrm{mg} / \mathrm{mL}$ and it can be accepted as higher DPPH antioxidant activity than the literature.

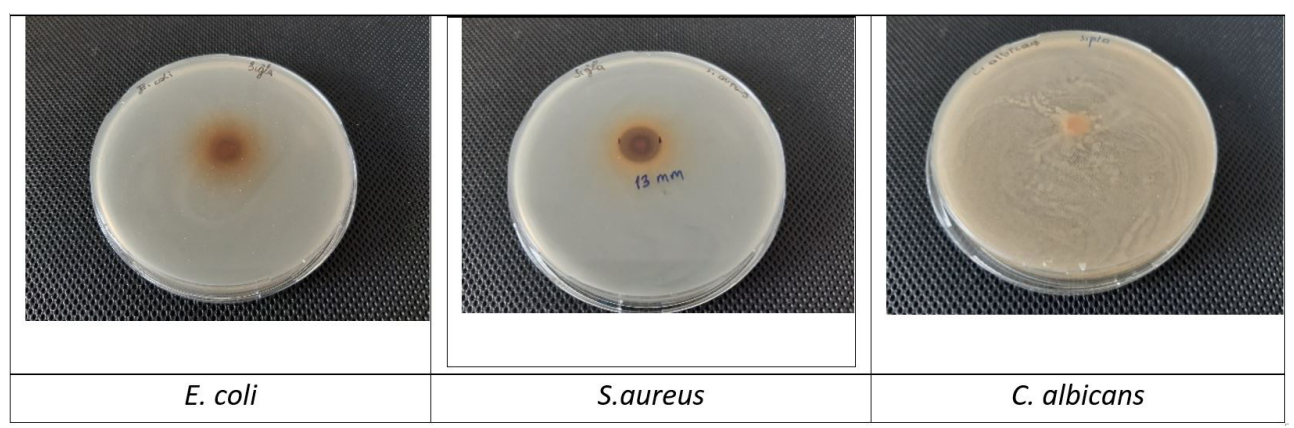

Figure 3. Photos of Inhibition Zone Diameters $(\mathrm{mm})$ for L. Orientalis extract. 
Table 2. Antimicrobial activity of $L$. orientalis medicinal plant.

\begin{tabular}{cccc}
\hline \multirow{2}{*}{ Samples } & \multicolumn{3}{c}{ Zone of Inhibition Diameters (mm) } \\
\cline { 2 - 4 } & E.coli & S. aureus & C. albicans \\
\hline L. orientalis & - & 13 & - \\
Amoxicillin+Clavulanic Acid & 16 & 20 & - \\
Nystatin & - & - & 19 \\
\hline
\end{tabular}

Notemean, Escherichia coli (E. coli) ATCC 25922, Staphylococcus aureus (S. aureus) ATCC 6538P, as yeast: Candida albicans (C. albicans) ATCC 14053, (-): no activity of test concentrations.

Table 3. MIC values of $L$. orientalis medicinal plant against the bacterial strains tested.

\begin{tabular}{cc}
\hline \multirow{2}{*}{ Samples } & $\begin{array}{c}\text { Minimal Inhibition } \\
\text { Concentration Values }(\mathbf{m g} / \mathbf{m L})\end{array}$ \\
\cline { 2 - 2 } & S. aureus \\
\hline L. orientalis & 10 \\
Amoxicillin+Clavulanic Acid & 40 \\
\hline
\end{tabular}

In a study conducted by Sağdıç et al. ${ }^{[31]}$, the antibacterial effect of the extract of the juice obtained from the wood and inner bark of the sweetgum tree in ethanol against various microorganisms was examined according to the disc infusion method and according to the result, $L$. orientalis secretion did not have any activity against E.coli while it has good antibacterial activity against $S$. aureus with its inhibition zone diameter of $14 \mathrm{~mm}$. Similarly, in our research, while the extract of $L$. orientalis leaf in water did not show any effect against $E$. coli, it showed a similar amount of activity against $S$. aureus with its inhibition zone diameter of $13 \mathrm{~mm}$.

In another study ${ }^{[32]}$, the antioxidant activities of $L$. orientalis plant extract obtained from Mugla Köyceiz using acetone, ethanol, and methanol solvents, as well as antimicrobial activities against eight test microorganisms, were investigated using the DPPH method, and it was discovered that they had strong antimicrobial and DPPH activity. It is assumed that this difference may be due to the change in extraction solvent and method used ${ }^{[29]}$.

Factors such as biological activity studies, composition and amount of active ingredients available in the plant, genetics (i.e. genus, species, cultivar/genotype) and geographical areas, growth conditions of plant material, climatic factors, ripening stage, harvest time, storage condition and postharvest management are also affects ${ }^{[33-35]}$.

Although there are antioxidant and antimicrobial studies on strains Liquidambar styraciflua $L^{[36-38]}$. ve Liquidambar formosana ${ }^{[39-41]}$, there are few reports on Liquidambar orientalis, an endemic species that we investigated. Especially studies on antioxidant activity are very limited, and only a few antioxidant activity studies have been conducted by using DPPH and $\mathrm{ABTS}^{+}$methods.

This study is significant in that it is the first study reporting the determination of both total flavonoid content and antioxidant content of $L$. orientalis plant leaf according to CUPRAC and FRAP methods, unlike the previous studies in the literature. In other words, it will be the first research to report the determination of all biological activities such as total polyphenol, flavonoid contents, antioxidant content, and antimicrobial activity for $L$. orientalis together, and will shed light on the scientists who will work on this species. Phenolic compounds are very essential and significant components of plants and the ability of phenolic compounds to scavenge radicals is due to their hydroxyl groups. Phenolic compounds can directly contribute to the antioxidative effect $^{[42]}$. Flavonoids are well-known antioxidants and natural phenolic compounds. The antioxidant efficacy of plant extracts rich in flavonoids is very high in various studies ${ }^{[43]}$.

\section{Conclusions}

This study demonstrated that aqueous extracts of L. orientalis have good antioxidant and antimicrobial activity. With a MIC value of $10 \mathrm{mg} / \mathrm{mL}$, it was found to have a higher antibacterial effect on $S$. aureus, a gram-positive bacterium that causes a wide variety of clinical diseases, even than Amoxicillin + Clavulanic acid, which is used as a standard drug in that field. Therefore, L. orientalis can be used as sources of natural antimicrobial agents. The antioxidant and antimicrobial properties of extracts obtained from a variety of plants are of great interest to academics as well as the food, cosmetics, and pharmaceutical industries. Since there is a growing trend to substitute synthetic preservatives with natural ones, they can be applied as natural additives. In this respect, it is very critical to work with endemic plant species and to reveal unknown bioactive properties. The results of this study indicate that $L$. orientalis plant leaf, which is an endemic species, contains compounds with antioxidant and antibacterial activity. Due to these activities, the leaf of this plant can be applied in the preparation of medicinal and nutritious products.

\section{References}

1. Göktaş, Ö., \& Gıdık, B. (2019). Uses of medicinal and aromatic plants. Bayburt Üniversitesi Fen Bilimleri Dergisi, 2(1), 145 151. Retrieved in 2021, May 15, from https://dergipark.org. tr/en/pub/bufbd/issue $/ 46478 / 515490$

2. Demiray, S., Pintado, M., \& Castro, P. (2009). Evaluation of phenolic profiles and antioxidant activities of Turkish medicinal plants: Tilia argentea, Crataegi folium leaves and Polygonum bistorta roots. World Academy of Science, Engineering and Technology, 3(6), 74-79. Retrieved in 2021, May 15, from https://publications.waset.org/10348/pdf

3. İșcan, G., Kirimer, N., Kürkcüoğlu, M., Başer, H. C., \& Demirci, F. (2002). Antimicrobial screening of Mentha piperita essential oils. Journal of Agricultural and Food Chemistry, 50(14), 39433946. http://dx.doi.org/10.1021/jf011476k. PMid:12083863.

4. Soković, M. D., Vukojević, J., Marin, P. D., Brkić, D. D., Vajs, V., \& van Griensven, L. J. L. D. (2009). Chemical composition of essential oils of Thymus and Mentha species and their antifungal activities. Molecules, 14(1), 238-249. http://dx.doi. org/10.3390/molecules14010238. PMid:19136911.

5. Kanatt, S. R., Chander, R., \& Sharma, A. (2008). Chitosan and mint mixture: a new preservative for meat and meat products. 
Food Chemistry, 107(2), 845-852. http://dx.doi.org/10.1016/j. foodchem.2007.08.088.

6. Yang, S.-A., Jeon, S.-K., Lee, E.-J., Shim, C.-H., \& Lee, I.-S. (2010). Comparative study of the chemical composition and antioxidant activity of six essential oils and their components. Journal of Natural Product Research, 24(2), 140-151. http:// dx.doi.org/10.1080/14786410802496598. PMid:20077307.

7. Güre, F., \& Arabacı, O. (2005). Natural antioxidants in some medicinal plants and their importance. In Turkey VI Field Crops Congress (pp. 465-470). Antalya, Turkey.

8. Meral, R., \& Doğan, İ. S. (2006). Antioxidant substances found in wheat. In Cereal Products Technology Congress. Gaziantep. Turkey.

9. Yarnell, E., \& Abascal, K. (2004). Botanical treatment and prevention of Malaria: part 2 - selected botanicals. Alternative and Complementary Therapies, 10(5), 277-284. http://dx.doi. org/10.1089/act.2004.10.277.

10. Kırca, A., Bilişli, A., Demirel, N. N., Turhan, H., \& Arslan, E. (2007). Antioxidant and antimicrobial activities of some medicinal and aromatic plants in Çanakkale flora. Tübitak Proje, (104), 292.

11. Leal-Cardoso, J. H., \& Fonteles, M. C. (1999). Pharmacological effects of essential oils of plants of the northeast of Brazil. Anais da Academia Brasileira de Ciências, 71(2), 207-213. PMid:10412491.

12. Baytop, T. (1984). Therapy with medicinal plants in Turkey. Istanbul, Turkey: Istanbul University Press.

13. Hafizoğlu, H. (1982). Analytical studies on the balsam of Liquidambar orientalis Mill. by gas chromatography and mass spectrometry. Holzforschung, 36, 311-313. http://dx.doi. org/10.1515/hfsg.1982.36.6.311.

14. Hafızoğlu, H., Reunanen, M., \& İstek, A. (1996). Chemical composition of levant storax. Holzforschung, 50, 116-117.

15. İstek, A., \& Hafizoğlu, H. (2005). Chemical components of Sweetgum tree (Liquidambar orientalis Mill.) wood bark. Kastamonu University Journal of Forestry Faculty, 5(1), 1-5. Retrieved in 2021, May 15, from https://dergipark.org.tr/tr/ pub/kastorman/issue/17248/180177

16. Slinkard, K., \& Singleton, V. L. (1977). Total phenol analysis: automation and comparison with anual methods. American Journal of Enology and Viticulture, 28, 49-55. Retrieved in 2021, May 15, from https://www.ajevonline.org/content/28/1/49

17. Chang, C.-C., Yang, M.-H., Wen, H.-M., \& Chern, J.-C. (2002). Estimation of total flavonoid content in propolis by two complementary colometric methods. Yao Wu Shi Pin Fen Xi, 10(3), 178-182. http://dx.doi.org/10.38212/2224-6614.2748.

18. Benzie, I. F. F., \& Szeto, Y. T. (1999). Total antioxidant capacity of teas by the ferric reducing/antioxidant power assay. Journal of Agricultural and Food Chemistry, 47(2), 633-636. http:// dx.doi.org/10.1021/jf9807768. PMid:10563944.

19. Apak, R., Güçlü, K., Özyürek, M., \& Karademir, S. E. (2004). Novel total antioxidant capacity index for dietary polyphenols and vitamins $\mathrm{C}$ and $\mathrm{E}$, using their cupric ion reducing capability in the presence of neocuproine: CUPRAC method. Journal of Agricultural and Food Chemistry, 52(26), 7970-7981. http:// dx.doi.org/10.1021/jf048741x. PMid:15612784.

20. Molyneux, P. (2004). The use of the stable free radical diphenylpicrylhyrazyl (DPPH) for estimating antioxidant activity. Songklanakarin Journal of Science and Technology, 26(2), 211-219. Retrieved in 2021, May 15, from http://rdo. psu.ac.th/sjstweb/journal/26-2/07-DPPH.pdf

21. Re, R., Pellegrini, N., Proteggente, A., Pannala, A., Yang, M., \& Rice-Evans, C. (1999). Antioxidant activity applying an improved ABTS radical cation decolorization assay. Free Radical Biology \& Medicine, 26(9-10), 1231-1237. http:// dx.doi.org/10.1016/S0891-5849(98)00315-3. PMid:10381194.
22. Collins, C. H., Lyne, P. M., \& Grange, J. M. (1995). Collins and Lyne's microbiological methods. UK: Hodder Education Publishers.

23. Clinical and Laboratory Standards Institute - CLSI. (2015). M07-A10: methods for dilütion antimicrobial susceptibility tests for bacteria that grow aerobically. Wayne: CLSI. Retrieved in 2021, May 15, from https://clsi.org/media/1632/m07a10_sample. pdf

24. Huang, D., Ou, B., \& Prior, R. (2005). The chemistry behind antioxidant capacity assays. Journal of Agricultural and Food Chemistry, 53(6), 1841-1856. http://dx.doi.org/10.1021/ jf030723c. PMid:15769103.

25. Zalibera, M., Staško, A., Šlebodová, A., Jančovičová, V., Čermáková, T., \& Brezová, V. (2008). Antioxidant and radical-scavenging activities of Slovak honeys: an electron paramagnetic resonance study. Food Chemistry, 110(2), 512-521. http://dx.doi.org/10.1016/j.foodchem.2008.02.015. PMid:26049247.

26. Chitme, H. R., Chandra, R., \& Kaushik, S. (2004). Studies on anti-diarrhoeal activity of Calotropis gigantea $\mathrm{R} . \mathrm{Br}$. in experimental animals. Journal of Pharmacy \& Pharmaceutical Sciences, 7(1), 70-75. PMid:15144737.

27. Palombo, E. A. (2011). Traditional medicinal plant extracts and natural products with activity against oral bacteria: potential application in the prevention and treatment of oral diseases. Evidence-Based Complementary and Alternative Medicine, 2011, 680354. http://dx.doi.org/10.1093/ecam/nep067. PMid:19596745.

28. Köse, M. D., Bayraktar, O., \& Balta, A. B. (2016). Antioxidant and antimicrobial activities of extracts from some selected Mediterranean plant species. International Journal of New Technology and Research, 2(5), 113-118. Retrieved in 2021, May 15 , from https://www.ijntr.org/antioxidant-and-antimicrobialactivities-of-extracts-from-some-selected-mediterranean-plantspecies

29. Ceylan, Ş., Saral, Ö., Özcan, M., \& Harşit, B. (2017). Determination of antioxidant and antimicrobial activities of blueberry (Vaccinium myrtillus L.) in different solvent extracts. Artvin Coruh University Journal of Forestry Faculty, 18(1), 21-27. http://dx.doi.org/10.17474/artvinofd.271088.

30. Saraç, N., \& Şen, B. (2014). Antioxidant, mutagenic, antimutagenic activities, and phenolic compounds of Liquidambar orientalis Mill. var. orientalis. Industrial Crops and Products, 53, 60-64. http://dx.doi.org/10.1016/j.indcrop.2013.12.015.

31. Sağdıç, O., Özkan, G., Özcan, M., \& Özçelik, S. (2005). A Study on inhibitory effects of sığla tree (Liquidambar orientalis Mill. var. orientalis) storax against several bacteria. Phytotherapy Research, 19(6), 549-551. http://dx.doi.org/10.1002/ptr.1654. PMid:16114094.

32. Okmen, G., Turkcan, O., Ceylan, O., \& Gork, G. (2014). The antimicrobial activity of a Liquidambar orientalis mill. against food pathogens and antioxidant capacity of leaf extracts. African Journal of Traditional, Complementary, and Alternative Medicines, 11(5), 28-32. http://dx.doi.org/10.4314/ajtcam. v11i5.4. PMid:25395700.

33. Ryan, T., Wilkinson, J. M., \& Cavanagh, H. M. A. (2001). Antibacterial activity of raspberry cordial in vitro. Research in Veterinary Science, 71(3), 155-159. http://dx.doi.org/10.1053/ rvsc.2001.0502. PMid:11798288.

34. Jimenez-Garcia, S. N., Guevara-Gonzalez, R. G., MirandaLopez, R., Feregrino-Perez, A. A., Torres-Pacheco, I., \& Vazquez-Cruz, M. A. (2013). Functional properties and quality characteristics of bioactive compounds in berries: biochemistry, biotechnology, and genomics. Food Research International, 54(1), 1195-1207. http://dx.doi.org/10.1016/j. foodres.2012.11.004. 
35. Lee, J., Dossett, M., \& Finn, C. E. (2012). Rubus fruit phenolic research: the good, the bad, and the confusing. Food Chemistry, 130(4), 785-796. http://dx.doi.org/10.1016/j. foodchem.2011.08.022.

36. Franco Mancarz, G. F., Pareja Lobo, A. C., Baril, M. B., Assis Franco, F., \& Nakashima, T. (2016). Antimicrobial and antioxidant activity of the leaves, bark and stems of Liquidambar styraciflua L. (Altingiaceae). International Journal of Current Microbiology and Applied Sciences, 5(1), 306-317. http:// dx.doi.org/10.20546/ijcmas.2016.501.029.

37. Mancarz, G. F. F., Laba, L. C., Silva, E. C. P., Prado, M. R. M., Souza, L. M., Souza, D., Nakashima, T., \& Mello, R. G. (2019). Liquidambar styraciflua L.: a new potential source for therapeutic uses. Journal of Pharmaceutical and Biomedical Analysis, 174, 422-431. http://dx.doi.org/10.1016/j. jpba.2019.06.003. PMid:31220700.

38. Cordier, W., Steenkamp, V., \& Rashed, K. (2016). An evaluation of antioxidant, anticholinesterase and antimicrobial activities of Liquidambar styraciflua L. leaves. Pharmaceutical Research, 14(2), 57-63. Retrieved in 2021, May 15, from https://tphres.innovesen.co.in/an-evaluation-of-antioxidantanticholinesterase-and-antimicrobial-activities-of-liquidambarstyraciflua-l-leaves

39. Liu, Y. M., Liu, Y. M., \& Li, P. X. (2009). Study on antimicrobial activities of essential oil from leaves of Liquidambar formosana
Hance as well as its antioxidant activity. Shipin Kexue, 30(11), 134-137. Retrieved in 2021, May 15, from http://www.spkx. net.cn/EN/Y2009/V30/I11/134

40. Shang, H.-J., Li, D.-Y., Wang, W.-J., Li, Z.-L., \& Hua, H.-M. (2014). Three new diterpenoids from the resin of Liquidambar formosana. Natural Product Research, 28(1), 1-6. http://dx.doi. org/10.1080/14786419.2013.825915. PMid:23962240.

41. DeCarlo, A., Zeng, T., Dosoky, N. S., Satyal, P., \& Setzer, W. N. (2020). The essential oil composition and antimicrobial activity of Liquidambar formosana oleoresin. Plants, 9(7), 822. http://dx.doi.org/10.3390/plants9070822. PMid:32629822.

42. Duh, P.-D., Tu, Y.-Y., \& Yen, G.-C. (1999). Antioxidant activity of water extract of harn jyur (Chyrsanthemum morifolium Ramat). Lebensmittel-Wissenschaft + Technologie, 32(5), 269-277. http://dx.doi.org/10.1006/fstl.1999.0548.

43. Cakir, A., Mavi, A., Yıldırım, A., Duru, E., Harmandar, M., \& Kazaz, C. (2003). Isolation and characterization of antioxidant phenolic compounds from the aerial parts of Hypericum hyssopifolium L. by activity-guided fractionation. Journal of Ethnopharmacology, 87(1), 73-83. http://dx.doi.org/10.1016/ S0378-8741(03)00112-0. PMid:12787957.

Received: May 15, 2021 Revised: June 01, 2021 Accepted: June 02, 2021 